\title{
AVALIAÇÃO DOS EFEITOS DE ALGUNS ACARICIDAS EM PEIXES ATRAVÉS DE TESTES DE TOXICIDADE
}

\section{SOLANGE RIBAS}

Mestranda do Curso de Pós-Graduação em Ciências Veterinárias. Coordenadora do Laboratório de Peixes do CEPPA Centro de Pesquisa e Processamento de Alimentos - Centro Politécnico - Universidade Federal do Paraná. Diretora de Estudos na área de Avaliação Toxicológica em Peixes.

A presença de agrotóxicos no ambiente aquático pode levar a danos severos para os organismos ali existentes. Em vista do risco potencial desses agrotóxicos realizou-se bioensaios para determinar a toxicidade de 5 agrotóxicos da classe acaricida no peixe Brachydanio rerio. Omite 720 CE, Malathion 500 CE, Karmat, Dimetrosan 400 CC e Danimem 150 SC. Para a realização do teste foi utilizada a metodologia do Manual do IBAMA que segue as normas de padrões internacionais como a OECD e EPA. Para o teste agudo foi utilizado o método semi-estático. Os peixes foram submetidos primeiramente a um teste preliminar para ser determinada 5 concentrações subletais para o teste definitivo de cada agrotóxico, e verificada a mortalidade nas seguintes horas de exposição ao produto: 02, 24, 48, 72 e 96 horas. Desta maneira foi encontrada a CL50 (concentração letal) de cada produto químico. Durante o teste foram observadas diariamente alterações morfológicas externas e comportamentais nos peixes e feita análises físico-químicas da água como $\mathrm{pH}$, condutividade, temperatura e concentração de oxigênio dissolvido. Os resultados mostravam que a maioria dos agrotóxicos da classe acaricida testados ficaram na classe IX ou seja, praticamente não tóxico (Karmat, Dimetrosam $400 \mathrm{CE}$ e Danimem $150 \mathrm{SC}$ ), não apresentando grandes alterações. O produto químico Malathion $500 \mathrm{CE}$ ficou na classe III sendo pouco tóxico e o produto Omite $720 \mathrm{CE}$ entrou na classe II como medianamente tóxico e causou grandes alterações morfológicas externas como perda da calota craniana, globo ocular para fora, coluna vertebral curvada e natação agitada. 